\title{
Distribution of Leiobunum limbatum L. Koch, 1861 (Opiliones: Sclerosomatidae) in Poland
}

\author{
Robert RozWALKA* and Wojciech STARĘGA** \\ *Department of Zoology, Maria Curie-Sklodowska University, Akademicka 19, 20-033 Lublin; \\ e-mail: arachnologia@wp.pl \\ **Department Institute of Biology, Siedlce University of Natural Sciences and Humanistics, Prusa 12, 08-110 Siedlce; \\ e-mail: wojstar@vp.pl
}

\begin{abstract}
Leiobunum limbatum is an expansive harvestman species of Alpine provenience connected with zone of hills and lower mountains. In the second half of 20 th and the beginning of 21 st century the species began its expansion to the East and North, mainly in Germany and the Czech Republic but reaching to Poland and even Sweden. The review of the new records shows that $L$. limbatum occurs in man-made habitats in the whole hill zone in Poland, from the Sudeten till the Bieszczady Mts. It is numerous, aggressive and competing successfully with local fauna.
\end{abstract}

Key words: Leiobunum limbatum, expansive harvestman, distribution in Poland

\section{INTRODUCTION}

Leiobunum limbatum L. Koch, 1861 is an Alpine harvestman which range primarily encompassed the French Alps, Switzerland, southern Germany, Austria, northern Italy and Slovenia. Moreover it lived in Böhmerwald/Šumava and reached even to the Harz Mountains (Šilhavý 1956, Martens 1978). Information of Roewer (1923), Kolosváry $(1929,1963)$ and Cârdei (1947) on its occurrence in Transylvania were wrong and has been questioned and corrected by many authors (Weiss 1996, Komposch 2004, Babalean 2005, Lengyel \&Murányi 2006, Murányi \& Lengyel 2006). Despite this Plăiaşu \& Băncilă (2008) continue credulously citing the data of Cârdei (1947) and treating occurrence L. limbatum as proved.

Already in 50-ties and 60-ties of 20th century isolated localities of L. limbatum were reported in Luxemburg (Muller 1962), central parts of Germany (Moritz 1973, Martens 1978, Sacher 1978) and southern Sweden (Martens 1978). In later years, further expansion has been noted in southern and central Germany (Bliss 1990) as well as in the Czech Republic (e.g. Bezděčka 1996, Klimeš \& Roušar 1998, Klimeš 1999) and quite recently (Bezděčka \& Bezděčková 2011) in eastern Slovakia. It continues and now the species is known even from the coast of the Baltic Sea (Lübeck, Stralsund, Sagard) (Staudt 2011). The number of localities in Scandinavia also increased but they are still restricted to southern Sweden (Stol 2003, 2007).

In Poland until quite lately only two localities were known, both at the foot of Śnieżnik Massif: Międzylesie [XR 15] and Jodlów [XR 25] (Rafalski 1985). It is worth mentioning that the specimens of Rafalski (1985) were collected in 1958, what univocally means that the species occurred in the Sudeten already in the fifties of 20th century. It was possibly an overlooked part of its natural range. Quite recently L. limbatum has been found in the nearest vicinity (may-be suburbs - no precise data!) of Szczecin (Staudt 2011). This locality is wrong error in gridmap-number of the record (A. Schönhofer and A. Staudt, pers. comm.). In fact it is in the vicinity of Görlitz and corresponds with the localities in eastern parts of Germany, next to the Polish border: Zittau, Cottbus, Görlitz (Bliss 1990), Berlin (Martens 1978), Stralsund 
and Sagard (Staudt 2011). Considering its seemingly rarity L. limbatum has been counted in the Polish Red List (Staręga et al. 2002) to the category EN (endangered). This needs revision as the species violently increases its range. The present paper is a proof of that ascertainment.

\section{LOCALITIES AND MATERIAL}

If not stated otherwise all material has been collected, observed and in major part determined by the first author. The second author determined only few earliest samples.

Localities with UTM squares are given in parantheses.

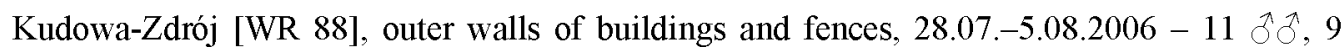
99,47 juv. Moreover very numerous specimens of both sexes were observed along the following streets: Jana Pawla II, Zdrojowa, 1. Maja, Kombatantów, Sloneczna, Moniuszki and on tree trunks and buildings in the city Park (Zdrojowy).

Góry Stolowe National Park [WR 88]: Błędne Skaly Mt, sandstone rock walls, 2.08.2006 - 1 $\hat{\jmath}, 4$ q, 12 juv.

Góry Stolowe National Park [WR 88]: Szczeliniec Wielki Mt, sandstone rock walls and crevices, $2.08 .2006-1 \AA, 6 q 9,16$ juv.

Czermna [WR 89], fences (wooden and brick), house walls along the streets Boleslawa Chrobrego and Kościuszki, numerous $\hat{\delta} \hat{\delta}$ and 9 , , 18.-21.09.2007 (obs.).

Duszniki-Zdrój [WR 98], wall of filling station, 17.09.2007-1 $\delta$ (obs.).

Lewin Klodzki [WR 98], shop wall, 17.09.2007 - 1 ठ.

Karlów [WR 99], house walls, $\pm 750 \mathrm{~m}$ a.s.1., 1.-3.08.2006 - 19 ; shop wall, 19.09.2007-1 9 .

Radków [WR 99], walls of the houses at Market, 19.09.2007-1 $\mathcal{A}, 1$ ( and observation of numerous further specimens).

Polanica-Zdrój [XR 08], house wall, 25.08.2008 leg. P. Bielak-Bielecki - 1 đ.

Nysa-Radoszyn [XR 69], wall of road-side bar, 22.09.2007- 1 .

Wroclaw-Śródmieście [XS 46], Ostrów Tumski, house walls, 19.10.2011 leg. P. BielakBielecki -1 . 9 .

Zawoja [CV 99], walls of the building of Babia Góra National Park management, 4.07.2008 - 4 juv.

Tatra Mts: Kościeliska Valley entrance [DV 15], walls of ticket office, 11.09.2009-19.

Chocholów [DV 16], wooden walls of T. Chałubiński Museum branch, 10.09.2009 leg. W. Cichocki \& R. Rozwalka - $7 \hat{\partial}, 2$ qq; many more specimens of both sexes observed on house walls and fences.

Witów [DV 16], shop wall, 10.09.2009 - 1 (obs.).

Czarny Dunajec [DV 17], brick fences and house walls, 10.09.2009-5 $\hat{\delta}, 4$ 우 and numerous further specimens (obs.).

Podczerwone [DV 17], wall of unused railway station, 10.09.2009-1 $\delta$ (obs.).

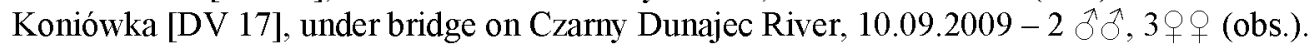

Zakopane-Kuźnice [DV 25], walls of station of the cable car to Kasprowy Wierch, 11.09.2009 $-4 \delta, 2$ oq and obs. of several further specimens.

Zakopane [DV 25], house walls, fences, tree trunks along the streets: Czecha, Droga na Bystre, Przewodników Tatrzańskich, 22.-23.08.2008, very numerous đ̊ đa and $q$ (obs.); Strążyska Str., wooden fence, 11.09.2009 - 1 ठ, 2 ㅇ; streets: Strążyska, Kasprusie, Orkana, house walls, fences, tree trunks, 11.09.2009- $\delta$ and $q 9$ (obs.).

Zakopane [DV 26], house walls, brick, wooden and even metal fences, tree trunks along the streets: 3. Maja, Chałubińskiego, Krupówki, Zamoyskiego, Kościuszki, 22.-23.08.2008 very numerous $\hat{\delta} \hat{\delta}$ and $q q$ obs.; Chalubińskiego Str., 8.09.-12.09.2009-10 $\hat{\partial}, 12 q q$ and obs. numerous further specimens along the streets: Chalubińskiego, Zamoyskiego, Krupówki, Zwierzyniecka. Also brick walls along the streets: Grunwaldzka, Orkana, 
Sienkiewicza, Tetmajera, 19.-30.09.2009 doc. phot. L. Grüm - numerous $\delta \hat{\delta}$ and $q 9$; in September 2011 completely absent in the same places - L. Grüm, personal comm.).

Zakopane-Harenda [DV 26], house walls, 29.06.-5.07.2009 - 12 juv. and many further specimens obs.

Poronin [DV 26], house walls, 3.07.2009 - 2 juv.

Nowy Targ [DV 28], wall of filling station, 22.08.2008 - 1 (obs.).

Palenica Bialczanska [DV 35], walls of wooden souvenir stalls by the parking place at the beginning of Morskie Oko hiking trail, 18.07.2008-1 $\delta, 9.09 .2009-1$.

Murzasichle [DV 36], house walls, 6.07.2011-3 juv.

Sromowce Niżne [DV 57], walls of educational pavillion of the Pieniny National Park, 7.07.2008 - 2 juv.

Niedzica [DV 57], house walls, 7.07.2008 - 5 juv.

Limanowa [DA 50], house wall, 1.08.2007-2 $\hat{\jmath} \hat{\text {. }}$.

Kamionka Mała [DA 61], inside of building, doc. phot. M. Szewczyk, 30.07.2007 - 1 q; obs.

R. Rozwałka, 30.-31.07.2007 - numerous $\hat{\partial} \hat{\jmath}$, +9 , and some specimens obs. (M.

Szewczyk) in the next year.

Żmiąca [DA 61], buildings, doc. phot. M. Szewczyk, 30.07.2007 - 1 juv; 03.11.2007 - 1 §; 10.11.2010 - 1 ?

Łososina Dolna [DA 71], house wall, 12.08.2007-2 $\hat{\jmath}, 1$ \%

Cisna [EV 95], brick wall of old cemetery, 17.08.2010 leg. J. Stachowicz - $2 \hat{\jmath} \jmath, 10$ juv.

Nowy Zagórz [EV 98], Krucza Str., on fence, 13.08.2011 - 1 ठ, 1 q.

Zagórz [EV 98], church wall, 13.08.2011-1 $\hat{\jmath}$; surrounding brick fence $-1 \hat{\delta}, 1$ (obs.).

Wetlina [FV 04], brick stakes of church fence, 18.08.2011 - 3 juv.; many further juv. on walls of houses, 18-20.08.2011 (obs.).

Ustianowa Dolna [FV 17], wall of filling station, 19.08.2010-1 $\partial$ (obs.).

Ustrzyki Dolne-Jasień [FV 17], sanctuary, belfry wall, 21.08.2011 - 1 q (obs.).

Ustrzyki Dolne [FV 17], house walls, brick and wooden fences along the streets: 1. Maja, 29.

Listopada, Belska, Konopnickiej, Krótka, Pionierska, Rynek, Szkolna, Wyzwolenia, 18.19.08.2008 - numerous $\hat{\partial} \hat{\partial}$ and $q 9$ leg. and obs.; house walls and fences along the streets Stokowa and Gombrowicza, 10.10.2010 - several $\hat{\partial} \delta$ and $q$ ㅇ (obs.).

Pszczeliny [FV 24], house wall, 20.08.2010-1 $\delta$.

Ustrzyki Górne [FV 24], walls of the building of Bieszczady National Park management, 19.08.2008 - $2 \widehat{\delta}, 3$ q ; and observation of numerous further specimens on wooden walls of different objects.

Krościenko nr Ustrzyki Dolne [FV 28], house wall, 19.08.2010 - 2 juv.

Other material:

The Czech Republic, Malá Čermná [WR 88], wall of beerhouse, 20.09.2007 - 2 đð (and several other specimens obs.).

\section{DISCUSSION}

Papers on harvestmen of South Poland are not numerous and therefore it is difficult to establish exactly the time of expansion of $L$. limbatum in the country. The very first mention of the species (Rafalski 1985) has been based on specimens collected in 1958. This is evidence that this harvestman lived in the Sudeten already in the 50-ties of the 20th century. The authors' observations from the vicinity of Klodzko point unequivocally that in the Sudeten Foreland the species is now very common and often the only harvestman in the man-made habitats. Taking into consideration its characteristic coloration (Fig. 1-4) and leg-span reaching 15 or even 19 centimetres one can for sure say, that it is impossible to overlook it or to mistake 
with any other Leiobunum species known from Poland, i.e. L. blackwalli Meade, L. rotundum (Latreille), L. rupestre (Herbst), L. tisciae Avram. It is therefore striking the lack of any information in papers dealing with Sudeten Highlands (Sanocka 1983, Sanocka \& Oślizło 1986) and the man-made habitats in the Babia Gora National Park by the end of 90-ties (Sanocka 2003). The papers on harvestmen of the Pieniny Mts (Staręga 1979) and the Bieszczady Mts (Staręga 1966) do not mention L. limbatum too, but they reflect the true situation because in 70-ties (Pieniny) and 60-ties (Bieszczady) the species did not reach these mountains yet.
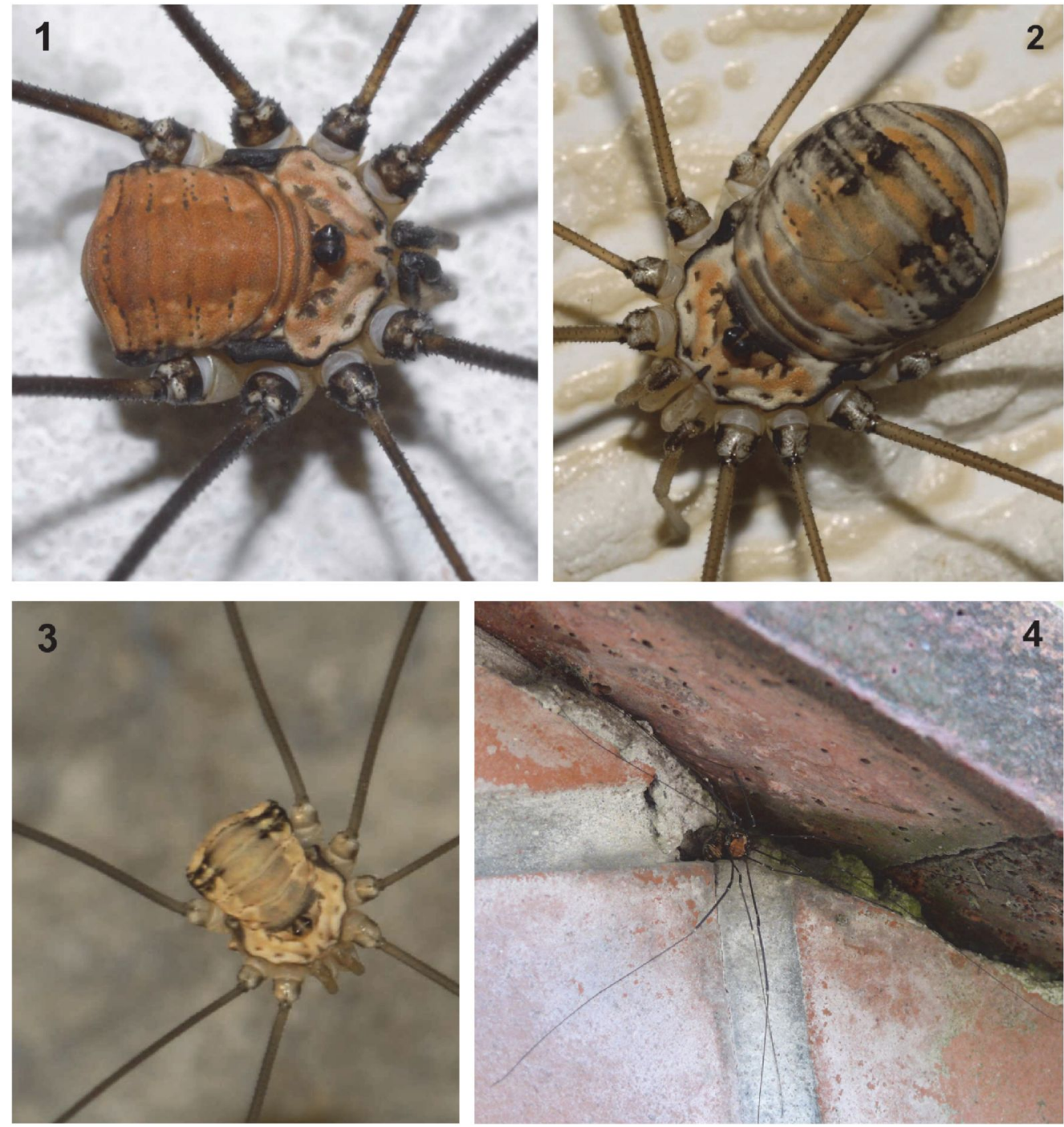

Figs 1-4. Leiobunum limbatum: 1 - male, 2 - female, 3 - juvenile (adults: Kamionka Mala, juv.: Żmiąca; phot. M. Szewczyk), 4 - couple on wall (Zakopane, phot. L. Grüm). 
Colonisation by L. limbatum of the whole hill and low mountains belt from the Sudeten all the way to the Bieszczady Mts indicates huge dispersion ability of the species. It is possible that some role plays here the anthropodispersion (perhaps transport of rock material, break stone or wood) but taking in consideration its great mobility and agility a good deal of its expansion must be due to autodispersion.

In spite of numerous localities in Austria (Martens 1978, Kofler 1984, Komposch \& Gruber 2004) and Slovenia (Novak et al. 2006, Šajna et al. 2009) the species has been recorded neither in Hungary (Komposch 2004) nor Croatia (Novak 2004). Similarly in the Czech Republic there are nearly 100 localities (e.g. Klimeš 1997, 1999, Klimeš \& Roušar 1998), even in the Bílé Karpaty Mts on Slovakian border (Bezděčka 1996), but no record from Slovakia (Bezděčka 2008, Stašiov 2008). It has been found in Slovakia quite recently (Bezděčka \& Bezděčková 2011). The absence of L. limbatum east of Slovenia and Austria is probably caused of its expansion mainly in northern direction (Fig. 5). The scarcity of information from Slovakia is due rather to the relatively poor knowledge of Slovakian harvestmen. Localities from Eastern Moravia (Bezděčka 1996) or herein presented Polish findings from the Orawa and Podhale regions (Zakopane, Podczerwone, Koniówka, Czarny Dunajec) and the Pieniny Mts (Niedzica, Sromowce Niżne) are lying nearly on Slovakian border. Very probable is also occurrence of $L$. limbatum in the Ukrainian part of the Bieszczady Mts what suggests Polish localities in Krościenko, Ustrzyki Dolne, Pszczeliny and Ustrzyki Górne (Fig. 6).

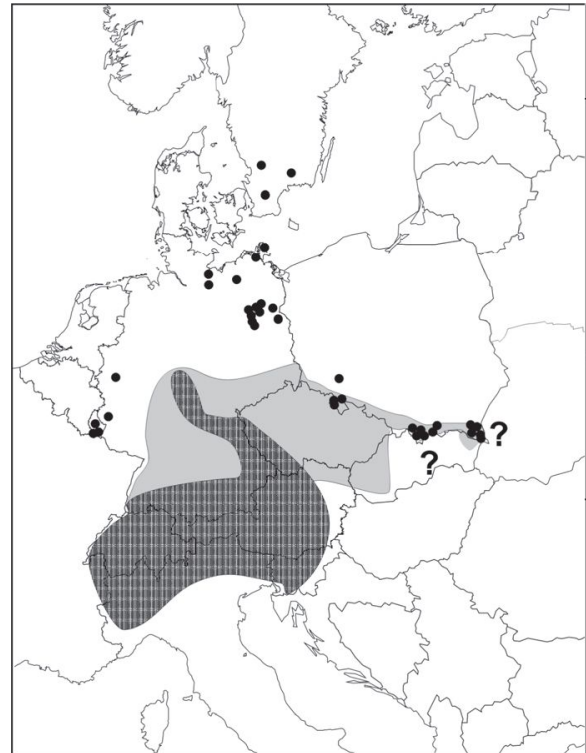

Fig. 5. General area of Leiobunum limbatum: white grid - distribution after Martens (1978) slightly changed, grey area - present range, black dots - localities reached during expansion.

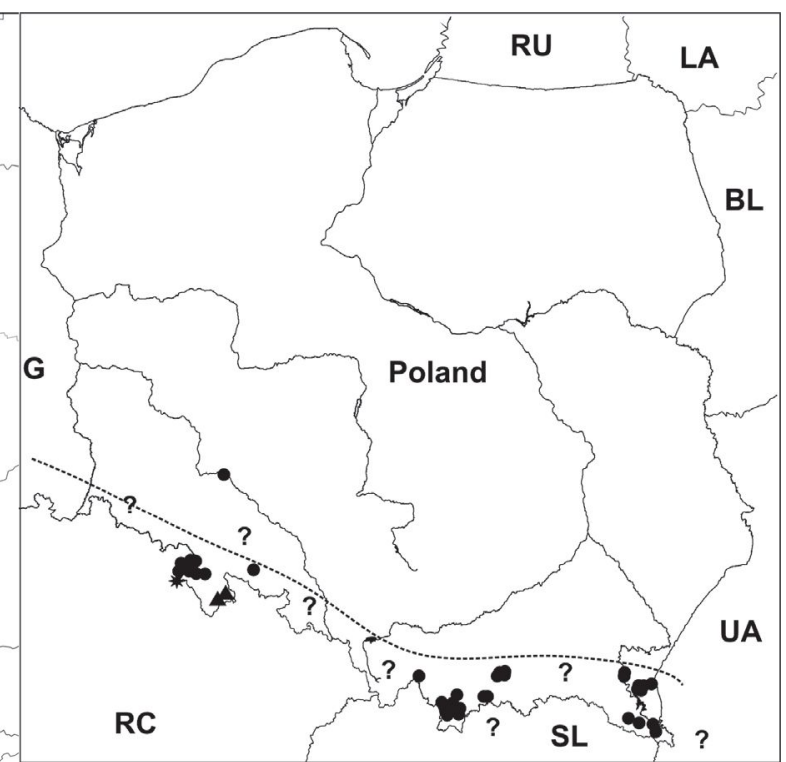

Fig. 6. Distribution of Leiobunum limbatum in Poland: circles new localities, triangles - localities from literature, stars - new locality in Czech Republic, question mark - possible occurrence, broken line - hypothetical northern range in Poland.

The Polish distribution map (Fig. 6) points unequivocally that L. limbatum occurs in the country along all foothills and low mountains and some breaks (e.g. the Beskid Zachodni Mts, the Beskid Wschodni Mts) are apparent and due to lack of data. The pattern of occurrence is in form of a narrow belt reaching north to Wroclaw but still not to Krakow and Rzeszow It is to some extent surprising because in the Czech Republic (Bezděčka 1996, Klimeš 1999) and Germany (Bliss 1990) the species inhabits man-made habitats in cities and towns. In Sweden, 
on the contrary, it lives mainly in deciduous and mixed forests and has been not found in manmade environment (Stol 2003).

Phenological data and observations gathered during our investigations show that $L$. limbatum is in Poland a late summer/autumn species, so no different from the populations in other Central European countries (Martens 1978). Only in Sweden the adults appear from March to November (Stol 2003).

Similarly as the other representatives of the genus Leiobunum, L. limbatum is active by night, hiding during day-time in folds and crevices of walls (Fig. 4) and rocks, fractures of bark etc. Observations in the Podhale region (Czarny Dunajec, Zakopane) exclude penetration of natural habitats (e.g. Quarry „Pod Capkami”), though the species is present in its next vicinity (Chałubiński Str. in Zakopane, Kuźnice).

Taking into consideration the herein presented data one can say that classifying of $L$. limbatum to endangered (EN) species in the Polish Red List (Staręga et al. 2002) is no more justified and must be changed. Results of observations in the Klodzko vicinity, the Podhale region, the Beskid Wyspowy Mts or the Bieszczady foothills indicate that L. limbatum is a very numerous species decidedly dominating in man-made environment. Records from KudowaZdrój, Zakopane and Ustrzyki Dolne point that it overcame (ate up?) the species traditionally living on buildings, like Mitopus morio (Fabr.), Opilio parietinus (De Geer), Phalangium opilio L. or other species from the genus Leiobumum C.L. Koch.

\section{ACKNOWLEDGEMENTS}

The authors wish to thank Dr Leszek Marian Szewczyk and Prof. Dr Leszek Grüm for kindly providing their information, observation and photographic documentation

\section{REFERENCES}

BABALEAN A. 2005. General overview on the Opilionid fauna (Arachnida, Opiliones) in Romania: Analele Ştiințifice ale Universității "A1.I. Cuza", Biologie animală 51: 47-54.

BEZDĔC̆KA P. 1996. První příspěvek k poznání sekáčú jihovýchodní Moravy (Arachnida, Opilionida). Sborník Př́rodovědného klubu v Uherském Hradišti 1: 52-55.

BEZDĔC̆KA P. 2008. Seznam sekáčů (Opiliones) České republiky [Checklist of harvestmen (Opiliones) of the Czech Republic]. Klapalekiana 44: 109-120.

BEZDĔC̆KA P., BEZDĚČKOVÁ K. 2011. Leiobunum limbatum - nový sekáč (Opiliones) pro Slovensko. Folia faunistica Slovaca 16: 31-34.

BLISS P. 1990. Leiobunum limbatum (Arachnida, Opiliones) in der DDR: Verbreitungsmuster, Synanthropie und Arealexpansion. Bulletin de la Société Européenne d'Arachnologie 1: 31-35.

CÂRDEI F. 1947. Beiträg zur Kenntnis der Opilionidenfauna von Maramureș. Revista științifica "V. Adamachi" 33: 157-158.

KLIMEŠ L. 1997. Harvestmen (Phalangida) assemblages in the Czech Republic. Acta Societatis zoologica Bohemica 61: 297-309.

KLIMEŠ L. 1999. Přehližení synantropní sekáči (Opiliones): novinky z česko-slovenského pomezí i odjinud. Sborník Př́rodovědného klubu v Uherském Hradišti 4: 68-71.

KLIMEŠ L., ROUŠAR A. 1998. Remarkable harvestmen from the Czech Republic. Arachnologische Mitteilungen 16: 33-39.

KOFLER A. 1984. Faunistik der Weberknechte Osttirols (Österreich) (Arachnida: Opiliones). Berichte des Naturwissenschaflich-Medizinischen Vereines in Innsbruck 71: 63-82.

KOLOSVÁRY G. 1929. Magyarország Kaszáspókjai. Die Weberknechte Ungarns (Opilionida). Studium Verlag, Budapest, 112 pp.

KOLOSVÁRY G. 1963. Opilionide dîn Transilvania (Weberknechte aus Siebenbürgen). Comunicârile Academiei Republici Populare Romine 6: 551-558.

KOMPOSCH C. 2004. The harvestman fauna of Hungary (Opiliones, Arachnida). In: F. SAMU \& C. SZINETÁR (eds.), European Arachnology 2002. Proceedings of the $20^{\text {th }}$ European Colloquium of Arachnology, Szombathely 22-26 July 2002, pp. 227-242.

KOMPOSCH C., GRUBER J. 2004. Die Weberknechte Österreichs (Arachnida, Opiliones). Denisia 12: 485 -534.

LENGyel G. D., MuRÁnyi D. 2006. Data to the Hungarian harvestman (Opiliones) fauna. Folia Historico-Naturalis Musaei Matraensis 30: 117-128.

MARTENS J. 1978. Weberknechte, Opiliones. Die Tierwelt Deutschlands, G. Fischer Verl., Jena, 64, 464 pp. 
MORITZ M. 1973. Neue und seltene Spinnen (Araneae) und Weberknechte (Opiliones) aus der DDR. Deutsche Entomologische Zeitschrift 20: 173-210.

Muller L. 1962. Les Phalangides dans le Grand-Duché de Luxembourg, Arach. Institut Grand-Ducal Luxembougeois des Sciences Naturelles, NS 28: 233-248.

MurÁNyi D., LENGYEL G. D. 2006. Contribution to the Opiliones fauna of Maramureş county, Romania. Studia Universitatis "Vasile Goldis" 17: 77-83.

NOVAK T. 2004. An overview of harvestmen (Arachnida: Opiliones) in Croatia. Natura croatica 13: 231-296.

Novak T., DELAKorda S. L., Novak L. S. 2006. A review of harvestmen (Arachnida: Opiliones) in Slovenia. Zootaxa 1325: 267-276.

PLĂIAŞU R., BĂNCILǍ R. 2008. The harvestmen fauna from the Maramureş Mountains Nature Park. Transylvanian Revue of Systematic and Ecological Research 5: 59-62.

RAFALSKI J. 1985. Leiobunum limbatum L. Koch nowy dla fauny Polski gatunek kosarza (Opiliones). Przegląd zoologiczny 29: 171-174

ROEWER C. F. 1923. Die Weberknechte der Erde. Systematische Bearbeitung der bisher bekannten Opiliones. G. Fischer Verl., Jena, 1116 pp.

SACHER P. 1978. Zum Vorkommen des Weberknechtes Leiobunum limbatum L. Koch in Gera (Opiliones: Phalangiidae), Veröffentlichungen der Museen der Stadt Gera (Naturwissenschaftliche Reihe) 6: 77-78.

SANOCKA E. 1983. Kosarze (Opiliones) strefy przełomów pod Książem (woj. wałbrzyskie), p. 124. In: GLOWACKAMigula E., SKowerska M., WoJCIECHOWSKI W. (eds), Postępy zoologii (Materiały informacyjne na XIII Zjazd Polskiego Towarzystwa Zoologicznego. Katowice, 1983). Wydawnictwo Uniwersytetu Śląskiego, Katowice.

SANockA E. 2003. Kosarze (Opiliones) masywu Babiej Góry, pp. 103-118. In: WOEOSZYN B.W., WOlOSZYN D., CELARY W. (eds), Monografia fauny Babiej Góry. Komitet Ochrony Przyrody PAN, Kraków, 494 pp

Sanocka E., Oślizlo D. 1986. Kosarze (Opiliones) Ziemi Nyskiej (woj. opolskie). Przegląd zoologiczny 30: 49-55.

STAREGA W. 1966. Kosarze (Opiliones) Bieszczad. Fragmenta Faunistica 13: 145-157.

StAREGA W. 1979. Kosarze (Opiliones) Pienin. Fragmenta Faunistica 24: 175-183.

StARĘGA W., Blaszak C., RAFAlskt J. 2002. Arachnida Pajęczaki. In: GlowactósKi Z. (ed.), Czerwona lista zwierząt ginących i zagrożonych w Polsce. Instytut Ochrony Przyrody PAN, Kraków, 133-140.

STAŠIOV S. 2008. Altitudinal distribution of harvestmen (Euchelicerata: Opiliones) in Slovakia. Polish Journal of Ecology 56: 157-163.

STAUDT A. 2011. Nachweiskarten der Spinnentiere Deutschlands. http:/www.arages.de/verbreitung.html

STOL I. 2003. Distribution and ecology of harvestmen (Opiliones) in the Nordic countries. Norwegian Journal of Entomology 50: 33-41.

STOL I. 2007. Checklist of Nordic Opiliones. Norwegian Journal of Entomology 54: 23-26.

ŠAJNA N., KUŠAR P., NOVAK L.S., NOVAK T. 2009. Notes on thermo- and hygropreference in Leiobunum roseum C. L. Koch, 1839 (Opiliones: Sclerosomatidae) in a habitat of Hladnikia pastinacifolia Reichenbach, 1831 (Spermatophyta: Apiaceae). Contributions to Natural History 12: 1111-1123.

ŠILHAVÝ V. 1956. Sekači - Opilionidea. Fauna ČSR 7, Nakladatelstvi Čs. Akad. Věd, Praha, 273 pp.

WEISS I. 1996. Die Weberknechtfauna Siebenbürgens (Arachnida: Opiliones). Stapfia 45: 259-280.

\section{STRESZCZENIE}

\section{[Rozmieszczenie Leiobunum limbatum L. Koch, 1861 (Opiliones: Sclerosomatidae) w Polsce]}

Leiobunum limbatum jest kosarzem pochodzenia alpejskiego, związanym ze środowiskami leśnymi i ścianami skalnymi polożonymi w strefie pogórzy i niskich gór. W drugiej polowie $\mathrm{XX}$ wieku odnotowano, że ten gatunek rozpoczal ekspansję w kierunku pólnocnym, skutkiem której rozprzestrzenil się na znacznym obszarze Niemiec i Czech docierając także do poludniowo-zachodniej Polski. Autorzy przedstawili szereg nowych danych, które wskazuja. że L. limbatum w Polsce jest znacznie szerzej rozmieszczony i występuje wzdluż calego pasa pogórzy od Sudetów po Bieszczady. Zaprezentowane nowe dane na temat występowania $L$. limbatum w Polsce sugeruja, że na pewno ten gatunek występuje także znacznie liczniej na Słowacji, a być może również w zachodniej Ukrainie. 